\title{
Role of Magnetic Resonance Imaging in Assessment of Pancreatic Iron Overload in Pediatric Beta-Thalassemic Major Patients
}

\author{
MOHAMED A. YOUSEF, M.D.*; IBRAHIM M. BADRAIA, M.D.**; MOHAMED M. ALASHWAH, M.D.* and \\ MEREHAN M. AHMED, M. S c. *
}

The Departments of Radiodiagnosis* and Pediatrics**, Faculty of Medicine, Tanta University

\begin{abstract}
Background: Thalassemia patients have diabetes mellitus subaltern to hemosiderosis.

Aim of Study: To asses iron overload in pancreas of pediatrics beta-thalassemia major patients by T2*-Gradientecho Magnetic Resonance Imaging (MRI) and to study correlation of results of data of MRI with affection with diabetes, serum ferritin level, hepatic hemosiderosis, and spleen removal.

Methods: 20 (3-thalassemia major patients with regular blood transfusion (11 males and 9 females) follow-up at the Hematology Clinic, Children's Hospital, Tanta University.

Results: Striking reduction in hepatic and pancreatic Signal Intensity Ratio (SIR) was appeared in thalassemic patients contrasted with controls $(p<0.001)$, Thalassemic patients with anomalous glucose tolerance; demonstrating a more level of secondary hemosiderosis in the form of low signal intensity of pancreas and liver tissue contrasted with thalassemics with typical glucose tolerance or controls $(p<0.001)$. Thalassemic patients with surgically removed spleen had essentially bring down SIR of pancreas contrasted with intact spleen patients $(p<0.047)$. A solid connection was available amongst hepatic and pancreatic siderosis in examined patients $(p<0.003)$.

Conclusions: T2* GRE MRI assume a vital part in detection of iron over-burden in B thalassemic patients, and was more obvious in patients with unusual glucose tolerance. After spleen removed, iron deposition might be more out of control in the pancreas. We prescribe serious chelation system to thalassemic patients generally and more in thalassemic patients with IGT with regular follow-up by susceptibility weighted sequences of magnetic resonance imaging.
\end{abstract}

Key Words: Pancreatic iron overload - MRI gradient echo imaging - Thalassemia.

\section{Introduction}

$\beta$-THALASSEMIA major is an inherited hemolytic anemia that is dealt with numerous blood

Correspondence to: Dr. Mohamed A. Yousef,

The Department of Radiodiagnosis, Faculty of Medicine, Tanta University transfusions which prompt iron over-burden, prompts cell demise and organ weakness [1]

Principle locales of iron collection are liver, spleen, heart and endocrine organ chiefly pancreas and pituitary organ. Chelation treatment has been utilized to dispose of it $[2,3]$.

Serum ferritin is the principle test done to assess press store, yet can prompt false outcomes if there should arise an occurrence of inflammation and liver sickness [4].

Liver is the primary site for iron storage in patients with hemochromatosis or transfusiondependent anemia; therefore, Liver Iron Concentration (LIC) accurately reflects total body iron stores [5] . Usually, liver iron overload evaluation is done by needle biopsy, which is invasive way carry a many of complication with it, and psychologically is un liked by patients [6]

Aggravation of the endocrine and exocrine elements of the pancreas is a known complexity in patients with beta-thalassemia major [7]. The extent of impaired glucose tolerance and diabetes in patients have thalassemia major is from $9 \%$ to $15 \%$ including on the time of assessment, the force of chelation, transfusion, and patient consistence [8]. The reason for diabetes in 3 -thalassemia is expanded fringe protection from insulin and direct poisonous impact of overabundance press in the acinar and beta cells of the pancreas bringing about insulin inadequacy [9].

Magnetic Resonance Imaging (MRI) is the most possible noninvasive strategy to assess hepatic iron substance and demonstrates a decent connection with biopsy comes about [10,11]. It is give us noninvasive technique for evaluating the level of iron in the liver and pancreas to affirming the finding, 
characterizing the seriousness and watching treatment with high affectability, specificity, and positive and negative predictive values [12].

\section{Patients and Methods}

Our study scanned 20 Egyptian $\beta$-thalassemia major patients ( 11 males, 9 females) regular transfuse blood at the Hematology Clinic, Pediatric Department Hospital, Tanta University, Tanta, Egypt in time from September 2016 to September 2017. Age went between 6-18 years (11.700 \pm 3.701). All thlassemic patients suffer from pallor and hepatomegaly. All patients were regular transfused blood each 2 to 4 weeks to save their hemoglobin level at $9-11 \mathrm{~g} / \mathrm{dl}$. Patients were advised to take chelation therapy with subcutaneous deferoxaminemesylate (Desferal,) (thirty to forty milligram/ kilogram body weight per day) or oral desferasirox (twenty to forty milligram/kilogram/day). Patients diseased with acute infection were briefly prohibited from the investigation to avoid the impact of disease on ferritin. Ferritin level ranged between (101-11000ng/dl) (Table 1). Spleen surgically removed in 14/20 patients (70\%). The studied patients were classified according to the results of fasting and post prandial glucose test (FG, PPG) into 15 patients with thalassemia major with Normal Glucose Tolerance (NGT) and 5 patients with abnormal glucose tolerance. Five healthy children, 3 males and 2 females; introduced as control group, in the same range of age of our patients, with normal CBC, serum ferritin and FBG and PPG. Informed consent was taken before the scan from all patients or their legal family.

Laboratory investigations: Complete Blood Count (CBC) was performed, Fasting Blood Glucose (FBG), Postprandial Blood glucose (PP).

\section{T2* MRI imaging technique:}

All MRI scans were done based on literature data with a $1.5 \mathrm{~T}$ scanner (GE medical system, sigma explorer). The pulse sequence used was T2weighted gradient-echo sequence TR $=13.9 \mathrm{~ms}$, the axial scan cuts must started just above the hepatic dome and extend down wards involving all pancreatic tissue including head, body and tail. The image was obtained in the axial plane, flip angle $35^{\circ}$; with 8 echo times, first echo time in $1 \mathrm{~ms}$ and interval was $1.3 \mathrm{~ms}[\mathbf{1 3}, \mathbf{1 4}]$.

\section{Image interpretation:}

We use (S. AX. Cardiac R2* BH) for measuring the signal intensity of organs. The intensity of the signals (SI) of the liver and pancreas were measured by 2 circles of interest (ROIs) of each that measured
$1 \mathrm{~cm}^{2}$, drown away from vessels, ducts and organ edges, and the average is calculated. The (S.AX. Cardiac R2*BH) introduce mean of signal intensity of different (ROIs) in form of $\mathrm{T} 2 *=(\mathrm{N})$ and $\mathrm{R} 2 *=$ (N) (N=number), $\mathrm{T} 2 *$ is indirectly proportional with iron overload, and $\mathrm{R} 2 *$ is directly proportional with iron overload. So, the hemosiderosis level in pancreas classified into (mild when R $2 *=30-100$ $\mathrm{Hz}$, moderate when $\mathrm{R} 2 *=100-400 \mathrm{~Hz}$ and sever when $\mathrm{R} 2 *>400 \mathrm{~Hz}$ ).

Table (1): Ferritin level of thalassemic of patients.

\begin{tabular}{llcl}
\hline & Range & Median & IQR \\
\hline Ferritin level (ng/dl) & $101-11000$ & 3400 & 3775 \\
HbF & $3-88$ & 29.5 & 29.5 \\
\hline
\end{tabular}

\section{Statistical analysis:}

Test of data was done by using Statistical Package for the Social Sciences (Version 17). We compared between thalassemic and controls, thalassemic non diabetic and diabetic of patients by using students $t$-test for parametric measures and mannWhitney U-test for non parametric measures. And to compared between controls, thlassemic non diabetic and thlassemic diabetic groups of patient byusing kruskal-wallis test. We were using pearson correlation coefficient also.

We considered $p$-value $<0.05$ as cut-off value for significance.

\section{Results}

Iron overload confirmed when $\mathrm{R} 2 *$ value of pancreas more than $30 \mathrm{~Hz}$ and classified according this $(30-100 \mathrm{~Hz}$ mild hemosiderosis, $100-400 \mathrm{~Hz}$ moderate and more than $400 \mathrm{~Hz}$ is sever). Pancreatic hemosiderosis appear in 17/20 (85\%) of patients. The intensity of signal of the liver and the pancreas were apparent decreased in thalassemic groups of patients in comparison to controls $(p<0.001)$ (Table $2)$. The range of $\mathrm{T} 2 *$ pancreas was between $(1.9$ and $24 \mathrm{~Hz}$ ) and $\mathrm{T} 2 *$ liver ranged between ( 1 and $19.6 \mathrm{~Hz}$ ).

Thalassemic patients with anomalous glucose tolerance showed more reduction in SIR of the liver and the pancreas compared to those with NGT $(p<0.001)$ as shown in (Table 2$)$. Signal intensity of pancreas was correlated with liver $(p<0.003)$ and with age of diagnosis $(p<0.002)$. Pancreatic SIR in our cases decreased when serum ferritin increased in most of cases denoting a negative correlation with serum ferritin $(p<0.004)$ as shown in (Table 3). 
Thalassemic patients with surgically removed spleen (12 case) showed clear reduction in intensity of signal of the pancreas compared to intact spleen patients (6 case) $(p<0.047)$.

Correlation of intensity of signal of pancreas with age, sex, family history and consanguinity history is not significant. Also correlation with hemoglobin level and platelet count and $\mathrm{HbF}$ showing no significance.

No correlation between interval of blood transfusion and signal intensity of pancreas.

$80 \%$ of hepatic siderosis is sever, $5 \%$ moderate and $15 \%$ mild, however, pancreatic siderosis is $25 \%$ sever, $40 \%$ moderate, $20 \%$ mild and $15 \%$ normal.

Table (2): Correlation between thalassemic patients (diabetic and non diabetic) and control in intensity of signal of pancreas.

\begin{tabular}{|c|c|c|c|c|c|}
\hline \multirow{2}{*}{ Diabetic } & \multicolumn{3}{|c|}{$\begin{array}{c}\mathrm{T} 2 * \text { pancreas } \\
(\mathrm{ms})\end{array}$} & \multicolumn{2}{|c|}{$\begin{array}{c}\text { Kruskal-Wallis } \\
\text { Test }\end{array}$} \\
\hline & Range & Median & IQR & $x^{2}$ & $p$-value \\
\hline \multirow{4}{*}{$\begin{array}{l}\text { Non diabetic } \\
\text { Diabetic } \\
\text { Controls }\end{array}$} & $2.6-42.5$ & 9.2 & 18.6 & 16.764 & $<0.001 *$ \\
\hline & $1.9-2.5$ & & 0.3 & & \\
\hline & $38-45$ & 41.5 & 4.25 & & \\
\hline & \multicolumn{3}{|c|}{ Mann-Whitney Test } & & \\
\hline \multicolumn{2}{|c|}{$N \& D$} & \multicolumn{2}{|l|}{$\mathrm{N} \& \mathrm{C}$} & \multicolumn{2}{|c|}{$\mathrm{D} \% \mathrm{C}$} \\
\hline \multicolumn{2}{|c|}{$0.001 *$} & $0.005^{*}$ & & \multicolumn{2}{|c|}{$0.008 *$} \\
\hline
\end{tabular}

Table (3): Correlation of ferritin level with pancreatic T2*.

\begin{tabular}{lll}
\hline Cases & Serum ferritin & T2* of pancreas \\
\hline 1 & 216 & $42.5 \mathrm{~ms}$ (normal) \\
2 & 2900 & $4.8 \mathrm{~ms}$ (moderate iron overload) \\
3 & 3990 & $9.1 \mathrm{~ms}$ (moderate iron overload) \\
4 & 6000 & $1.9 \mathrm{~ms}$ (sever iron overload) \\
5 & 1000 & 39.5 (normal) \\
6 & 1000 & $19.2 \mathrm{~ms}$ (mild iron overload) \\
7 & 3400 & $2.6 \mathrm{~ms}$ (moderate iron overload) \\
8 & 1100 & $25.2 \mathrm{~ms}$ (mild iron overload) \\
9 & 4144 & $6.6 \mathrm{~ms}$ (moderate iron overload) \\
10 & 101 & $37 \mathrm{~ms}$ (normal iron overload) \\
11 & 1900 & $14.5 \mathrm{~ms}$ (mild iron overload) \\
12 & 1600 & $7.5 \mathrm{~ms}$ (moderate iron overload) \\
13 & 2800 & $2 \mathrm{~ms} \mathrm{(sever} \mathrm{iron} \mathrm{overload)}$ \\
14 & 3500 & $10.1 \mathrm{~ms}$ (mild iron overload) \\
15 & 5000 & $3.5 \mathrm{~ms}$ (moderate iron overload) \\
16 & 11000 & $9.2 \mathrm{~ms}$ (moderate iron overload) \\
17 & 5000 & $7.1 \mathrm{~ms}$ (moderate iron overload) \\
18 & 3400 & $2 \mathrm{~ms}$ (sever iron overload) \\
19 & 10000 & $2 \mathrm{~ms}$ (sever iron overload) \\
20 & 7850 & $2.2 \mathrm{~ms}$ (sever iron overload) \\
\hline
\end{tabular}

Correlation between serum ferritin and $\mathrm{T} 2 *$ of pancreas. $r=0.610, p$-value $=0.004$.

Moderate negative significant correlation.
Cases:

Case No. 1:
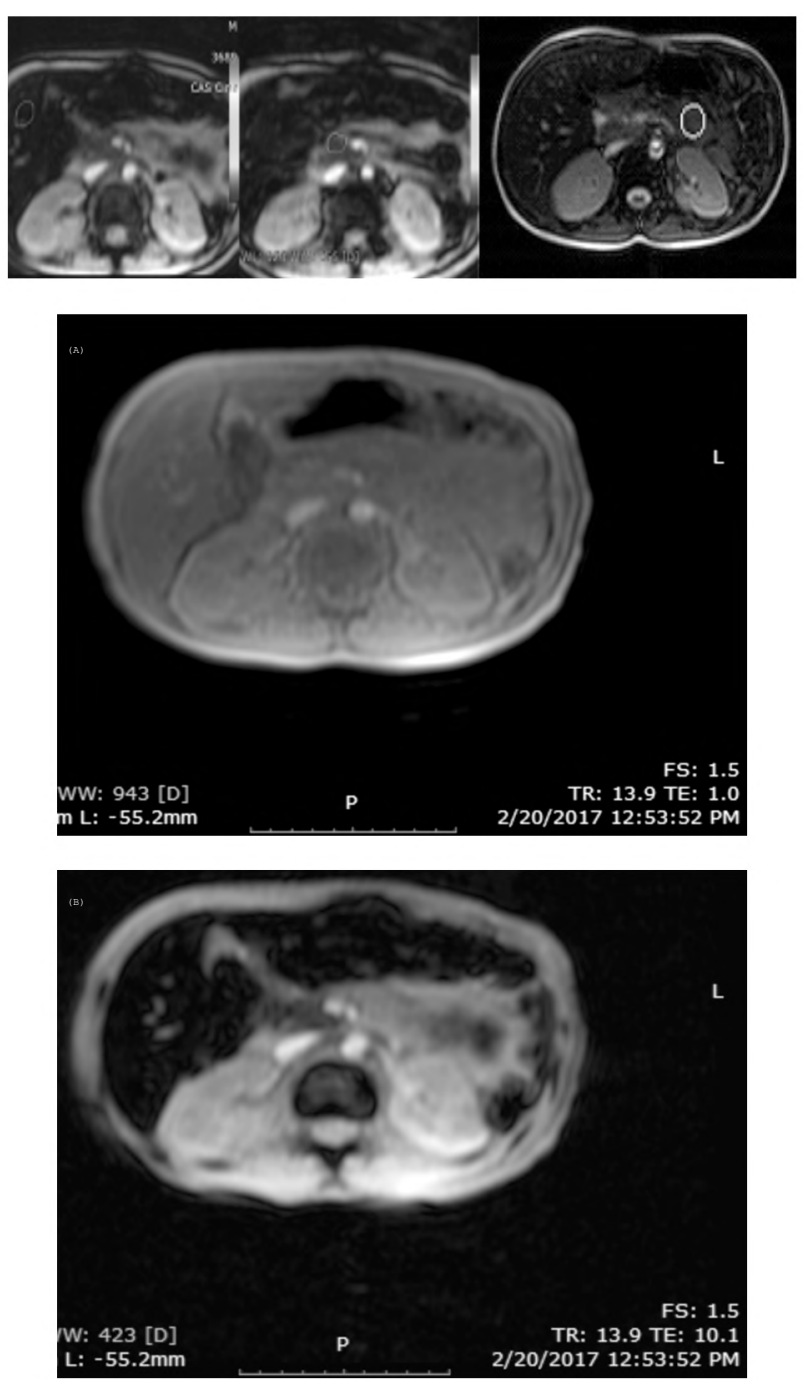

Fig. (1): Axial images showing manually drawn ROI of liver and head and body of pancreas.

Fig. (1) MRI T2* multi-echo sequence of upper abdominal cut of male patient aged 9 years old, diagnosed as B-thalassemia major at 2 years with $\mathrm{Hb} \mathrm{F}=25 \%$ ( $\mathrm{N}$ up to $=1 \%$ ), $\mathrm{Hb}=6 \mathrm{~g} / \mathrm{dl}$, platlate count $=506000 / \mathrm{cmm}$ and blood transfusion every 6 weeks. Serum ferritin level=3990ng/ml. And splenectomy is done (TR $13.9 \mathrm{~ms}$, flip angle 35 , TE first $=1 \mathrm{~ms}$, TE interval $=1.3 \mathrm{~ms}, 8$ echoes, acquisition time: $14.5 \mathrm{~s}$ ) showing loss of signal intensity of liver and pancreas from the first echoes. Denoting irone overload.

- $\mathrm{T} 2 *$ of pancreas $=9.1 \mathrm{~ms}$.

- $\mathrm{T} 2 *$ of liver $=2.9 \mathrm{~ms}$.

Diagnosis: Moderate heamsiderosis of pancreas and liver. 
Case No. 2:
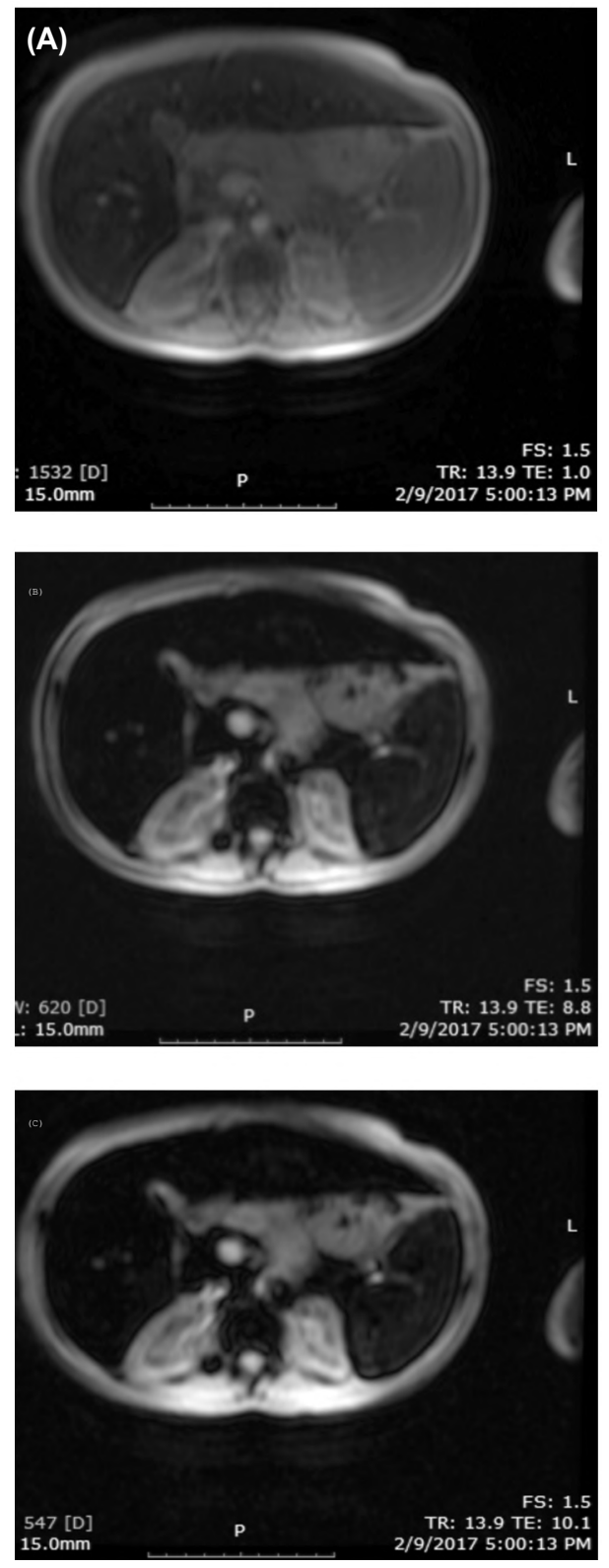

Fig. (2):

MRI T2* multi-echo sequence of upper abdominal cut of female patient aged 10 years, diagnosed as thalassemic at 1 month with $\mathrm{Hb} F=14 \%$ ( $\mathrm{N}$ up to $=1 \%), \mathrm{Hb}=7 \mathrm{mg} / \mathrm{dl}$, platlate count $=506000 \mathrm{mg} / \mathrm{dl}$, blood transfusion avery 15 day. Serum ferreten level $=6000 \mathrm{ng} / \mathrm{ml}$ and not splenectomized. The patient is diabetic also (TR $13.9 \mathrm{~ms}$, flip angle 35 , TE first $=1 \mathrm{~ms}$, TE interval $=1.3 \mathrm{~ms}, 8$ echoes, acquisition time: $14.5 \mathrm{~s}$ ) showing loss of signal intensity of liver and pancreas from the first echoes. Denoting irone overload.

- $\mathrm{T} 2 *$ of pancreas $=1.9 \mathrm{~ms}$.

- $\mathrm{T} 2 *$ of liver $=1.4 \mathrm{~ms}$.

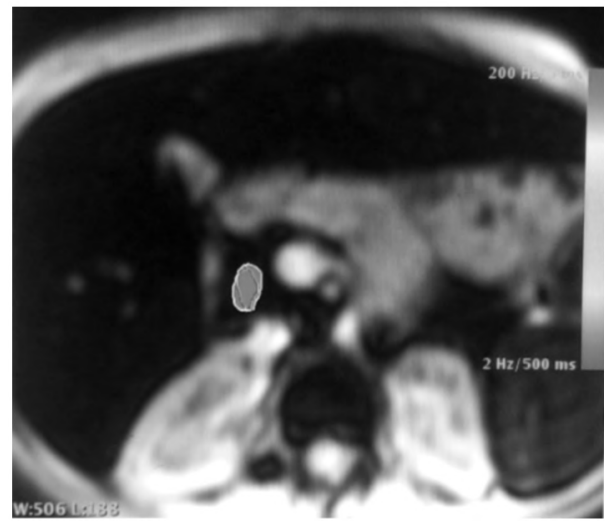

Fig. (3): Axial images showing manually drawn ROI of liver and head and body of pancreas.

\section{Diagnosis:} betes.

Sever pancreatic heamsiderosis leading to dia-

Sever heamsiderosis of liver.

\section{Discussion}

Magnetic Resonance (MR) imaging is the most sensitive and specific imaging test in the diagnosis of organ iron overload in thalassemic patients dependent blood transfusion. The effect caused by the iron overload leads to signal loss in the affected tissues, particularly with the T2* weighted sequences, which give us noninvasive way to diagnose iron over-burden without biopsies [15]

The amassing of iron particles in the tissues, in light of the superparamagnetic properties of the iron, causes neighborhood twisting in the magnetic fields and relaxation of the spins which results in shortening of the longitudinal relaxation time (T1) and the transverse relaxation time (T2), and particularly the transverse relaxation time as affected by magnetic field inhomogeneity $\left(\mathrm{T} 2^{*}\right)$. This effect causes a loss of signal intensity in the affected organs that is proportional to the iron deposition [16] .

In our examination, we utilize the single breath $\mathrm{T} 2 *$ gradient echo sequence because of its short filtering time which is more advantageous in youngsters.

The percent of diabetes in thalassemia major patients is $25 \%$ and this come in concurrence with different examinations changed from $8 \%$ up to $27 \%[17-19]$.

In our thalassemic patients with strange glucose tolerance showed higher serum ferritin contrasted 
with patients with Normal Glucose Tolerance is in concurrence with khalifa et al., as serum ferritin cause destruction of pancreatic cells leading to glucose disturbance $[\mathbf{1 9 , 2 0 ]}$.

Our examination showing hepatic and pncreatic lower signal intensity ratio of patients with thalassemia contrasted with controls (Table 2); the conclusion of hepatic siderosis was show up in $20 / 20$ patients $(100 \%)$ (15\% mild, $5 \%$ moderate and $80 \%$ sever) and analysis of pancreatic siderosis was in $17 / 20$ patients $(85 \%$ ) (20\% mild, $40 \%$ moderate and 25\% sever). Midiri et al., Papakonstantinou et al., Au el al. and Noetzli et al., said that pancreatic secondary hemosiderosislead toabnormal dark MRI signal, and there is press over-burden in the pancreas in thalassemic major cases up to 75-100\% [21-24].

Our examination additionally recognized lower signal power of the liver and pancreas in thalassemic patients with abnormal glucose in connection with patients with ordinary glucose tolerance (Table 2), in concurrence with Matter et al., 2010 and Doaa Mohammad Youssef et al., what's more, in concurrence with Papakonstantinou et al., $[22,34,35]$

Au et al., result was decreased in iron overload in pancreas with age, so $\mathrm{T} 2 *$ increase in this case, in other hand, Christoforidis said that there was a decrease of $\mathrm{T} 2 *$ of liver with increasing of age $[23,25]$. Lastly, our result of this part of study was positive significant relation between iron overload in liver and pancreas and age of diagnosis, but, no relation was seen with age of patients.

We watched additionally negative noteworthy connection between's serum ferritin and SIR of the pancreas (Table 3), like Midiri et al., [21] yet not concurrence with others [22,26]. Argyropoulou et al., stated that there was no relationship between, $\mathrm{s}$ pancreatic iron deposition/siderosis and serum ferretin.Argyropoulou et al., said the way that T2 relaxation time relies upon not onlysiderosisbut also fatty invasion of the pancreas [26].

Likewise, negative relationship between's serum ferritin and intensity of signal of liver in our considered patients was distinguished in concurrence with numerous examinations [22,26-29]; while no comparative connection was noted in different investigations $[25,30]$.

We detect a strong relationof pancreatic $\mathrm{T} 2 *$ and hepatic T2*. This result was like Brewer et al., [31], but no similar correlation in Papakonstan- tinou et al., Au el al., and Noetzli et al., [22-24,32]; this conflict may be due to their patients are adult and pancreatic parenchyma is replaced by fat which is affect values of MRI.

At last, we distinguish likewise huge decrease in pancreatic signal in surgically removed spleen thalassemic patients contrasted with those with in place spleen in concurrence with Doaa Mohammad Youssef et al., [35]. This due to lack of other store for iron as spleen in our case $[\mathbf{3 1}, \mathbf{3 3}, \mathbf{3 4}]$. For this, surgically removed beta thalassemia major patients ought to be entirely observed for pancreatic iron over-burden by MRI to maintain a strategic distance from pancreatic brokenness.

We saw that inclusion of children B thalassemic patients who not affected yet by fatty infiltration and many other disease is the main advantage of our study, and all of them are examined in one MRI machine and same doctors. The main study limitation is our patient are very young, so they afraid from MRI machine and need every time psychological sedation. However, we hope in the future that MRI used in detection of risky thalassemic patient who exposed to diabetes to prevent there affection.

\section{Summary and Conclusion:}

Striking decrease in the liver and the pancreatic signal was appeared in thalassemic patients contrasted with controls $(p<0.001)$, Thalassemic patients with anomalous glucose tolerance; demonstrating a more level of secondary hemosiderosis of liver and pancreas in form of lower signal intensity of their tissues contrasted with thalassemics with typical glucose tolerance or controls $(p<0.001)$. Thalassemic patients with surgically removed spleen had essentially bring down SIR of pancreas contrasted with intact spleen patients $(p<0.047)$. A solid connection was available amongst secondary hemosiderosis of liver and pancreas in examined patients $(p<0.003)$.

T2* gradient weighted MRI assume a vital part in detection of iron over-burden in B thalassemic patients, and was more obvious in patients with unusual glucose tolerance. After spleen removed, iron deposition might be more out of control in the pancreas. We prescribe serious chelation system to thalassemic patients generally and more in thalassemic patients with IGT with regular followup by susceptibility weighted sequences of magnetic resonance imaging to survey change of secondary hemosiderosis of pancreatic tissue. 


\section{References}

1- ARGYROPOULOU M.I. and ASTRAKAS L.: MRI evaluation of tissue iron burden in patients with 3 -thalassaemia major. Pediatric Radiology, 37 (12): 1191-200, 2007.

2- RUND D. and RACHMILEWITZ E.: Medical progress: $\beta$-thalassemia. The New England Journal of Medicine, 353 (11): 1135-46, 2005.

3- HERSHKO C., LINK G., KONIJN A.M. and CABANTCHIK Z.I.: Objectives and mechanism of iron chelation therapy. Annals of the New York Academy of Sciences, 1054: 124-35, 2005.

4- WOOD J.C. and GHUGRE N.: Magnetic resonance imaging assessment of excess iron in thalassemia, sickle cell disease and other iron overload diseases. Hemoglobin, 32 (1-2): 85-96, 2008.

5- TZIOMALOS K. and PERIFANIS V.: Liver iron content determination by magnetic resonance imaging. World Journal of Gastroenterology, 16 (13): 1587-97, 2010.

6- ANGELUCCI E., BARONCIANI D., LUCARELLI G., et al.: Needle liver biopsy in thalassaemia: Analyses of diagnostic accuracy and safety in 1184 consecutive biopsies. British Journal of Haematology, 89 (4): 757-61, 1995.

7- KATTAMIS C., LADIS V., TSOUSSIS D., KALOUMENOU I. and THEODORIDIS C.: Evolution of glucose intolerance and diabetes in transfused patients with thalassemia. Pediatric Endocrinology Reviews, 2 (2): 26771, 2004.

8- LI C.K., LUK C.W., LING S.C., et al.: Morbidity and mortality patterns of thalassaemia major patients in Hong Kong: Retrospective study. Hong Kong Medical Journal, 8 (4): 255-60, 2002.

9- CARIO H., HOLL R.W., DEBATIN K.M.M. and KOHNE E.: Insulin sensitivity and 3 -cell secretion in thalassaemia major with secondary haemochromatosis: Assessment by oral glucose tolerance test. European Journal of Pediatrics, 162 (3): 139-46, 2003.

10- ANDERSON L.J., HOLDEN S., DAVIS B., et al.: Cardiovascular T2-star $(\mathrm{T} 2 *)$ magnetic resonance for the early diagnosis of myocardial iron overload. European Heart Journal, 22 (23): 2171-9, 2001.

11- WOOD J.C., ENRIQUEZ C., GHUGRE N., et al.: MRI $\mathrm{R} 2$ and $\mathrm{R} 2 *$ mapping accurately estimates hepatic iron concentration in transfusion-dependent thalassemia and sickle cell disease patients. Blood, 106 (4): 1460-5, 2005.

12- ALÚSTIZA J.M., CASTIELLA A., De JUAN M.D., EMPARANZA J.I., ARTETXE J. and URANGA M.: Iron overload in the liver diagnostic and quantification. European Journal of Radiology, 61 (3): 499-506, 2007.

13- GANDON Y., OLIVIÉ D., GUYADER D., AUBÉ C., OBERTI F., SEBILLE V. and DEUGNIER Y.: Noninvasive assessment of hepatic iron stores by MRI. Lancet, 363 (9406): 357-362, 2004.

14- BONKOVSKY H.L., RUBIN R.B., CABLE E.E., DAVIDOFF A., RIJCKEN T.H. and STARK D.D.: Hepatic iron concentration: Non invasive estimation by means of MR imaging techniques. Radiology, 212 (1): 227-34, 1999.
15- M. QUEIROZ-ANDRADE, R. BLASBALG, C.D. ORTEGA, et al.: "MR imaging findings of iron overload," Radiographics, Vol. 29, No. 6, pp. 1575-89, 2009.

16- A.C.A. WESTPHALEN, A. QAYYUM, B.M. YEH, et al.: "Liver fat: Effect of hepatic iron deposition on evaluation with opposed-phase MR imaging," Radiology, Vol. 242, No. 2, pp. 450-5, 2007.

17- CARIO H., HOLL R.W., DEBATIN M. and KOHNE E.: Insulin sensitivity and beta cellsecretion in thalassaemia major with secondary hemochromatosis: Assessment by oral glucose tolerance test. Eur. J. Pediatr., 162 (3): 13946, 2003.

18- ONG C.K., LIM S.L., TAN W.C., ONG E.E. and GOH A.S.: Endocrine complications intransfusion dependent thalassaemia in Penang Hospital. Med. J. Malaysia, 63 (2): 109-12, 2008.

19- KHALIFA A.S., SALEM M., MOUNIR E., EL-TAWIL M.M., EL SAWY M. and ABD AL-AZIZ M.M.: Abnormal glucose tolerance in Egyptian Beta thalassemic patients: Possible association with genotyping. Pediatr. Diabetes, 5 (3): 126-32, 2004.

20- CHERN J.P., LIN K.H., LU M.Y., LIN D.T., LIN K.S., CHEN J.D. and FU C.C.: Abnormal Glucosetolerance in transfusion-dependant beta-thalassemic patients. Diabetes Care, 24 (5): 850-4, 2001.

21- MIDIRI M., LO CASTO A., SPARACIA G., D'ANGELO P., MALIZIA R., FINAZZO M., MONTALTO G., SOLBIATI L., LAGALLA R. and De MARIA M.: MR imaging of pancreatic changes inpatients with transfusiondependent beta-thalassemia major. A.J.R. Am. J. Roentgenol., 173 (1): 187-92, 1999.

22- PAPAKONSTANTINOU O., LADIS V., KOSTARIDOU S., MARIS T., BERDOUSI H., KATTAMIS C. and GOURTSOYIANNIS N.: The pancreas in beta-thalassaemia major: MRImaging features and correlation with ironstores and glucosedisturbances. Eur. Radiol., 17 (6): 1535-43, 2007.

23- AU W.Y., LAM W.W., CHU W., TAM S., WONG W.K., LIANG R. and HA S.Y.: A T2* magnetic resonance imaging study of pancreatic iron overload inthalassemia major. Hematologica, 93 (1): 116-9, 2008.

24- NOETZLI L.J., PAPUDESI J., COATES T.D. and WOOD J.C.: Pancreatic iron loadingpredicts cardiac iron loading in thalassemia major. Blood, 114 (19): 4021-6, 2009.

25- CHRISTOFORIDIS A., HARITANDI A., TSITOURIDIS I., TSATRA I., TSANTALI H., KARYDA S., DIMITRIADIS A.S. and ATHANASSIOU-METAXA M.: Correlative study of ironaccumulation in liver, myocardium, and pituitary assessed with MRI inyoung thalassemic patients. J. Pediatr. Hematol. Oncol., 28 (5): 311-5, 2006.

26- ARGYROPOULOU M.I., KIORTSIS D.N., ASTRAKAS L., METAFRATZI Z., CHALISSOS N. and EFREMIDIS S.C.: Liver, bone marrow, pancreas and pituitary gland ironoverload in young and adult thalassemic patients: A T2 relaxometrystudy. Eur. Radiol., 17 (12): 3025-30, 2007.

27- GANDON Y., OLIVIE D., GUYADER D., AUBE C., OBERTI F., SEBILLE V. and DEUGNIER Y.: Noninvasive assessment of hepatic iron stores by MRI. Lancet, 363 (9406): 357-62, 2004. 
28- CHRISTOFORIDIS A., PERIFANIS V., SPANOS G., VLACHAKI E., ECONOMOU M., TSATRA I. and ATHANASSIOU-METAXA M.: MRI assessment of liver iron content inthalassamic patients with three different protocols: Comparisons andcorrelations. Eur. J. Haematol., 82 (5): 388-92, 2009

29- LEUNG A.W., CHU W.C., LAM W.W., LEE V. and LI C.K.: Magnetic resonance imagingassessment of cardiac and liver iron load in transfusion dependentpatients. Pediatr. Blood Cancer, 53 (6): 1054-9, 2009.

30- ARGYROPOULOU M.I., KIORTSIS D.N. and EFREMIDIS S.C.: MRI of the liver and thepituitary gland in patients with beta-thalassemia major: Does hepaticsiderosis predict pituitary iron deposition? Eur. Radiol, 13 (1): 126, 2003.

31- BREWER C.J., COATES T.D. and WOOD J.C.: Spleen $\mathrm{R} 2$ and $\mathrm{R} 2 *$ in iron-overloadedpatients with sickle cell disease and thalassemia major. J. Magn. Reson. Imaging, 29 (2): 357-64, 2009.

32- PAPAKONSTANTINOU O., ALEXOPOULOU E.,
ECONOMOPOULOS N., BENEKOS O., KATTAMIS A., KOSTARIDOU S., LADIS V., EFSTATHOPOULOS E., GOULIAMOS A. and KELEKIS N.L.: Assessment of iron distribution between liver, spleen, pancreas, bone marrow, and myocardium by means of $\mathrm{R} 2$ relaxometry with MRI in patients with beta-thalassemia major. $\mathbf{J}$. Magn. Reson. Imaging, 29 (4): 853-9, 2009.

33- HASSAN M. YAISH, M.D.: Pediatric Thalassemia Treatment \& Management. Thalassemia, 2007.

34- R.M. MATTER, K.E. ALLAM and A.M. SADONY: "Gradient-echomagnetic resonance imaging study of pancreatic iron overloadin young Egyptian betathalassemiamaj or patients and effect ofsplenectomy," Diabetology \& Metabolic Syndrome, Vol. 2, No. 1, article 23, 2010.

35- DOAA MOHAMMED YOUSSEF, et al.: Assessment of Hepatic and Pancreatic Iron Overload inPediatric BetaThalassemic Major Patients by T2* Weighted Gradient Echo Magnetic Resonance Imaging. Hindawi Publishing CorporationISRN Hematology Volume, Article ID 496985, 5 pages, 2013.

\section{دور الرنين المغناطيس لقياس نسبة تربس الحلديد فى الكبد والبنكرياس

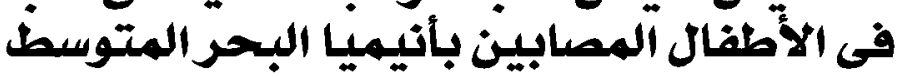

$$
\begin{aligned}
& \text { مرض آنيميا البحر الآبيض المتوسط من آكثر الآمراض الجينية الوراثية شيوعا، يتميز بمعالجته بنقل دم متكرد. العرض الجانبي المشهود }
\end{aligned}
$$



$$
\begin{aligned}
& \text { وظائفها. } \\
& \text { هنال طرق لقياس مستوى الحديد فى الدم في المعامل لكنها غير دقيقة لقياس ترسب هذا الحديد في الآعضاء خصوصا في حالات الإلتهابات }
\end{aligned}
$$

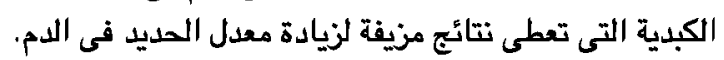

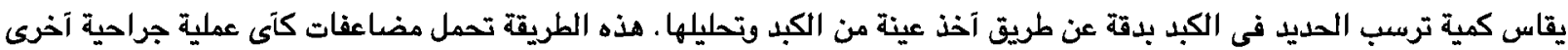

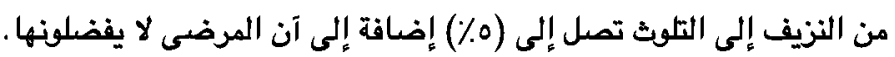

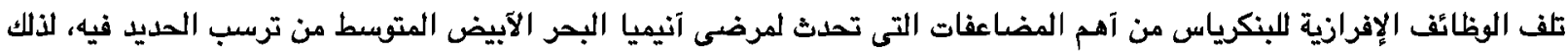

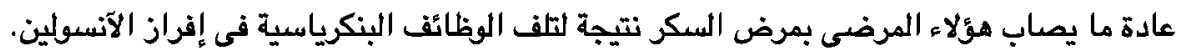

$$
\begin{aligned}
& \text { الرنين المغناطيسى من آفضل الطرق لقياس نسبة ترسب الحديد في الكبد والبنكراس بطريقة غير جراحية وغير مؤذية. } \\
& \text { وبعد دراسة قيمة هذا الموضوع تبين آن: إنخفاض شعديد في درجة الإثارة في رنين كبد وبنكرياس مرضى آنيميا البحر الآبيض المتوبط } \\
& \text { مقارنة بغير المرضى. } \\
& \text { الغير مصابين به. }
\end{aligned}
$$

